\title{
Optimal Sanitary Landfill Site Selection for Solid Waste Disposal in Durgapur City Using Geographic Information System and Multi-criteria Evaluation Technique
}

\author{
Md Mainul Sk ${ }^{1} \cdot$ Sk Ajim Ali $^{1} \cdot$ Ateeque Ahmad $^{1}$
}

Received: 2 March 2020 / Accepted: 16 September 2020 / Published online: 5 November 2020

(c) The Author(s) 2020

\begin{abstract}
The government authorities in developing countries are awfully concerned with coping out the problems of the rising issues related to the disposal of solid wastes. Most of the Indian cities still dispose of solid waste unscientifically causing to severe environmental as well as public health problems. Geographic information systems (GIS) and analytic hierarchy process (AHP) have emerged as efficient tools for multiple criteria decision analysis (MCDA) in effective solutions of solid waste management. The present study focuses on the integration of GIS and AHP in identifying potential sanitary landfill areas for solid waste disposal in Durgapur city, West Bengal, India. Eleven criteria were selected viz. land elevation, slope, soil, geology, land use land cover, distance to surface water, distance to tube wells, distance to roads, distance to industrial belts, distance to sensitive places, and land cost. All the criteria were aggregated using weighted overlay analysis in GIS environment. The study identified three potential landfill areas for MSW disposal covering the areas of $13.83854,33.80678$, and 27.20085 ha, respectively, in Durgapur city. The result found that land cost value was the most significant criterion in the model with a weight of 0.25258 . Followed by land cost value, sensitive places and roads were the second and third most important criteria with a weight value of 0.1409 and 0.1233 , respectively.
\end{abstract}

Keywords AHP MCDA · GIS · Decision support system · Landfill site · SWM

\begin{abstract}
Abstrakt
Die Regierungsbehörden in Entwicklungsländern sind stets bemüht, die zunehmenden Probleme im Zusammenhang mit der Entsorgung von Feststoffabfällen zu bewältigen. Die meisten indischen Städte entsorgen noch immer feste Abfälle auf unwissenschaftliche Art und Weise, was zu schweren Umwelt- und Gesundheitsproblemen führt. Geographische Informationssysteme (GIS) und der Analytische Hierarchieprozess (AHP) haben sich als effiziente Werkzeuge für die MehrkriterienEntscheidungsanalyse (MCDA) in effektiven Lösungen für das Feststoffabfallmanagement herauskristallisiert. Die vorliegende Studie konzentriert sich auf die Integration von Geographischen Informationssystemen (GIS) und dem Analytischen Hierarchieprozess (AHP) bei der Identifizierung potenzieller Sanitärdeponiegebiete für die Entsorgung fester Abfälle in der Stadt Durgapur, Westbengalen, Indien. Elf Kriterien wurden ausgewählt: Landhebung (LE), Neigung (SL), Boden (SI), Geologie (GL), Landnutzung und Landbedeckung (LULC), Entfernung zu Oberflächenwasser (DSW), Entfernung zu Rohrbrunnen (DTW), Entfernung zu Straßen (DR), Entfernung zu Industriegürteln (DIB), Entfernung zu empfindlichen Orten (DSP) und Landkosten (LC). Alle Kriterien wurden mit Hilfe der gewichteten Überlagerungsanalyse (WOA) in einer GIS-Umgebung aggregiert. Die Studie ermittelte drei potenzielle Deponiebereiche für die Entsorgung fester Siedlungsabfälle mit einer Fläche von 13,83854, 33,80678 bzw. 27,20085 ha in der Stadt Durgapur. Das Ergebnis verdeutlichte, dass der Wert der Grundstückskosten mit einem Gewicht von 0,25258 das wichtigste Kriterium in dem Modell war. Gefolgt vom
\end{abstract}

Md Mainul Sk

mainulsk1991@gmail.com

1 Department of Geography, Faculty of Science, Aligarh

Muslim University, Aligarh, UP, India 
Grundstückskostenwert waren sensible Orte und Straßen das zweit- und drittwichtigste Kriterium mit einem Gewicht von 0,1409 bzw. 0,1233 .

\section{Introduction}

By World Population Clock, 2020, India is the second most populated country in the world having a population of more than 137 cores, accounting for $17.7 \%$ of the world's total population, and $35.0 \%$ of the total Indian is living in the urban areas. Unprecedented population growth, rapid urbanization and industrialization, fast economic growth, the influx of rural migrants to urban areas and changing consumption pattern of urban residents have accelerated the solid waste generation dramatically and solid waste has become the major environmental concern posing a menace to the survival of living being (Allen and Macarthy 1997). India is getting buried under the heap of trash and garbage as the country generates solid waste of 1.50 lakh MT daily (Shrivastava 2019) and this is projected to reach 300 MT annually by the end of 2047 (CPCB 2000). Approximately 15,000 MT of solid waste out of 1.50 lakh MT is remained uncollected and about 108,000 MT or $80 \%$ of the total collected waste is disposed in landfill sites daily without considering any processing (Shrivastava 2019).

In India, municipal solid waste is collected and disposed of in landfills unscientifically (Yadav 2007) that become the breeding grounds for rodents, flies, and birds resulting in chaotic situations (CPCB 2001; Suchitra 2007). The decomposition of solid waste produces landfill gases (LFG), i.e., methane $\left(\mathrm{CH}_{4}\right)$, carbon dioxide $\left(\mathrm{CO}_{2}\right)$ and other trace gasses (MeBean et al. 1995; Suchitra 2007; IPCC-AR5 2014). Methane is nontoxic gas; yet, it is extremely combustible, explosive and causes the smoldering of solid waste leading to air pollution (Abdul-Wahab 2004). Besides methane, several toxic and volatile air pollutants (e.g., vinyl chloride and tetrachloroethylene) are released from landfills (Lauber 2005) that proliferate the health problems among the residents in close proximity to landfill sites (Shah 2007). The unscientific landfills also degrade the quality of drinking water through the penetration of leachate into groundwater (Tripathi et al. 2006); and cause jaundice, nausea, asthma, miscarriage, and infertility (El-Fadel et al. 1971). Inadequate management of solid waste coupled with hot climatic conditions adversely affects the environment at the local level as well as global facet (Taylan et al. 2007; Sumathi et al. 2008).

The final destination of solid waste is the disposal, and it is an important element of SWM. There are several methods of disposal of wastes practiced worldwide such as thermal treatment or incineration, buried, biological treatment or composting, and landfills. Landfills are still most widely practiced method in low and medium-income countries, because it is relatively simple and cost-effective (Sumathi et al. 2008; Kim and Owens 2010). Establishment of the solid waste landfill is a tedious errand as it may adversely impact on the country's economy, ecology, and environmental health, if an unsuitable site is selected without considering any decision-making process (Chang et al. 2008; Che et al. 2013).

Many factors such as environmental, political and legislations are integrated into landfill siting decisions, and geographic information system (GIS) is an ideal tool to administer bulky volumes of spatial data from different sources (Peuquet and Marble 1990; Klosterman 1995; Savage et al. 1998; Yaakup et al. 2004; Nas et al. 2010; Chandio et al. 2012), because it has the capability to store, retrieve, analysis and demonstrations of data as per the requirement of the users (Malczewski 2006; Mat et al. 2016). The application of GIS and multiple criteria decision analysis (MCDA) techniques is useful for spatial multi-criteria decision analysis (Ali and Ahmad 2020), and since the last 2 decades, it has been extensively used by the researchers (Sumathi et al. 2008; Delgado et al. 2008; Geneletti 2010; Chandio et al. 2012; Eskandari et al. 2012; Uyan 2013; Arkoc 2014; Yal and Akgün 2013). In most of these researches, the analytic hierarchy process (AHP) has been applied as criterion weights method (Demesouka et al. 2013). AHP is a widely applied method in decision-making problems concerning multiple criteria analysis (Tavares et al. 2011) and is applied in the field of MSWM for suitable landfill site selection (Yagoub and Buyong 1998; Raghupati 1999; Patil et al. 2002; Natesan and Suresh 2002; Despotakis and Economopoulos 2007; Lotfi et al. 2009; Nishanth et al. 2010; Şener et al. 2010, 2011; Kara and Doratli 2012).

The most significant aspect is that before designing any strategic plan for the MSWM system, long term recorded data regarding the quantity of dumping waste is necessary but there is no recorded data on the daily basis in the study area. The existing landfill site used by the Durgapur Municipal Corporation (DMC) presently for solid waste disposal is located outside of the city boundary and characterized with small in size which is going to be filled in the near future. The present landfill site is located close to an irrigated canal and open agriculture field. The site observation revealed that leachate from the landfill site migrates into the canal as well as in the agricultural field in rainy seasons which adversely affects the soil and water quality. Besides, being the open landfill sites the waste especially the plastics or polythene blown away and dumped in the agricultural field causing troubles to farmers in cultivating. Thus, systematic management of solid waste is imperative both for the conservation 


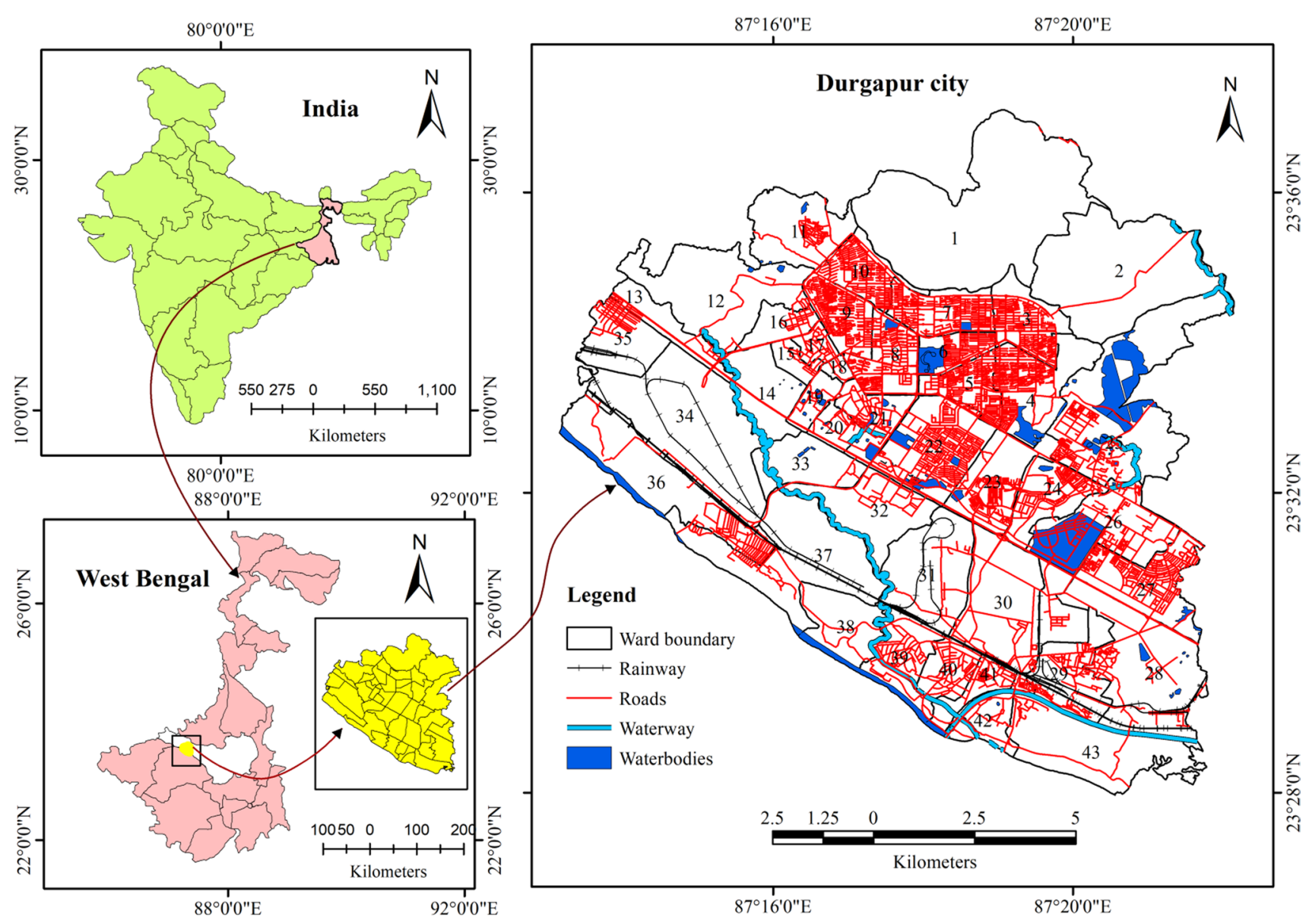

Fig. 1 Location map of the study area

of natural resources and the prevention of environmental pollution (Banar et al. 2007).

To maintain environmental sustainability and to diminish the adverse impacts on environment and health, the existing solid waste management (SWM) system in Durgapur must be improved; incorporating adequate collection, employing sound transfer methods and healthy disposal practices. Therefore, the present study aims to identify the optimal sanitary landfill site for solid waste disposal in Durgapur city of India, in combining with GIS and the analytic hierarchy process (AHP).

The Arc-GIS software includes the spatial analysis function which facilitates the identification and collection of spatial data, weighing of criteria with AHP, data integration and GIS analysis, and output evaluation. The Arc GIS acts as a platform to overlay the multiple factors to provide a composite map which is considered as a best-fitted land for any development (Chandio et al. 2012).

\section{Materials and Methods}

\subsection{Description of the Study Area}

Durgapur city (Fig. 1) is located on the left bank of the river Damodar at a distance of $160 \mathrm{~km}$ from Kolkata, the state capital in the state of West Bengal in between $87^{\circ} 13^{\prime} \mathrm{E}$ to $87^{\circ} 22^{\prime} \mathrm{E}$ longitude and $23^{\circ} 28^{\prime} \mathrm{N}$ to $23^{\circ} 36^{\prime} \mathrm{N}$ latitude. Durgapur is one of the significant post-independent industrial towns and came into existence as a Notified Area Authority in 1962 and was upgraded to the status of a Municipal Corporation in 1996. Durgapur has an area of about $154.2 \mathrm{~km}^{2}$ with population density $3891 \mathrm{~km}^{-2}$ (excluding floating population). Administratively, Durgapur Municipal Corporation (DMC) comprises of 5 boroughs and 43 electoral wards; each borough includes a cluster of wards.

The climate of Durgapur is experienced by a transitional climate between the tropical wet and dry climate and the humid subtropical climate. Winter is pleasant here December and January are the coldest months of the year. The average temperature of the cold months ranges $18-19{ }^{\circ} \mathrm{C}$ with 
Table 1 GIS map layers used in the study

\begin{tabular}{lll}
\hline Data & Scale & Data source \\
\hline Geological structure & $1: 250,000$ & GSI (Geological Survey of India) \\
Soils & $1: 250,000$ & $\begin{array}{c}\text { NBLSR (National Bureau of Land } \\
\text { and Soil Survey) }\end{array}$ \\
Surface water bodies & $1: 250,000$ & Google Earth Pro \\
Slope & $1: 250,000$ & SRTM \\
Land use/land cover & $1: 250,000$ & Sentinal-2 \\
Roads & $1: 250,000$ & Open street map \\
Sensitive places & $1: 250,000$ & Google Earth Pro \\
Industrial belts & $1: 250,000$ & Google Earth Pro \\
Land cost value & $1: 250,000$ & Personal discussion with residents \\
Tube wells and wells & $1: 250,000$ & CGWB, India \\
Land elevation & $1: 250,000$ & SRTM \\
\hline
\end{tabular}

the lowest recorded temperatures range $6-7^{\circ} \mathrm{C}$ in January. The temperature in the summer months varies $35-45^{\circ} \mathrm{C}$; occasionally shoot up to about $47^{\circ} \mathrm{C}$. The settled rainy season is the months of July through September $80-85 \%$ of the total annual rainfall occurs during this period.

DMC currently generates nearly 250 ton day $^{-1}$ (TPD) of solid waste daily with $404 \mathrm{~g}$ (2016) per capita per day. At present total secondary collection points are around 116 and several open dumps, including 124 dual containers and 57 single containers covering the whole city. Based on the future population expected by 2045, the amount of Municipal Solid Waste (MSW) has been projected as 488 TPD. From the containers' points of view, DMC vehicles pick up the solid garbage and transport it to the disposal ground. A mechanized compost plant of $224 \mathrm{t} \mathrm{day}^{-1}$ capacity was installed at Shankarpur by DMC in 2008 with the implementation of Jawaharlal Nehru National Urban Renewal Mission (JNNURM) in collaboration with Hanjer Biotech Energies Durgapur Private Limited. However, the plant is almost nonfunctional now, due to a lack of demand for compost in the market.

\subsection{Data Base}

In this study, the integration of geographic information systems (GIS) and analytic hierarchy process (AHP) was emphasized in identifying potential sanitary landfill areas for solid waste disposal in Durgapur city, India. GIS data sets of the study area such as geology, soil types, tube wells and wells, land-use, surface water bodies, roads, land cost value, industrial belts, and digital elevation models (DEMs) were collected for Durgapur city from different sources (such as Geological Survey of India, National Bureau of Landuse and Soil Survey, Central Ground Water Board, Google Earth Pro, Durgapur Municipal Corporation). Geology, soils, land use, tube wells and wells maps on a particular scale were collected from different sources and digitized subsequently. Land elevation and slope maps were prepared based on the Shuttle Radar Topography Mission (SRTM) data with $10 \mathrm{~m}$ resolution. They are summarized, as shown in Table 1. The digitization and analyses of maps were carried out in a GIS environment. The AHP systematically breaks up the decision problems into understandable parts; each of these parts was assessed separately and integrated in a logical manner (Demesouka et al. 2013). Eleven criteria were selected for the site selection, based on MSWM Rules (2016) and published literature. To evaluate each criterion, the rank method was applied. Lower the rank better is the suitable site and vice versa (Table 2). In this study, eleven input map layers including geology, soils, tube wells and wells, land-use, surface water bodies, roads, land cost value, industrial belts, and digital elevation were collected and prepared in a GIS environment. All layers were converted into the individual raster map (Sener et al. 2006; Şener et al. 2011). AHP weights were calculated in MS office. The required geographical features were extracted by exploiting Arc-GIS for the analysis. All these GIS data sets were converted and reclassified into the same projection system (WGS-1984) and in equal cell size. The constraints are shown in Table 3. At first, constraints were masked.

\subsection{Landfill Selection Criteria}

A suitable landfill site must be placed and designed to meet the essential conditions for checking the contamination of groundwater, surface water and pollution of the soil. Besides, settlement and built-up aspects must be considered for landfill site selection to protect public health. Also, the landfill site should be located near to the existing roads to the transportation and collection costs (Aziz and Khodakarami 2013). The major factors that are inevitable in sitting of MSW landfills have been dogged in the first step. In this study, eleven criteria have been selected for evaluating landfill suitability. These entire criteria have been chosen according to the standard and regulations for landfills sitting in India and from published literature considering the case study situations. The structured hierarchical scheme model of this study is presented in Fig. 2. The separate map was produced for each suitability criterion and a final composite map was finally obtained by Weighed Overlay Analysis. The analysis of selected criteria for landfill site selection is illustrated in the following sections.

\subsubsection{Land Elevation}

Land elevation largely affects the construction and operation of the landfill sites and must be taken into account 
Table 2 Ranking values for the selected criteria

\begin{tabular}{|c|c|c|c|c|}
\hline Goal & Criterion & Sub-criteria/alternatives & $\begin{array}{l}\text { Suitability } \\
\text { index (rank- } \\
\text { ing) }\end{array}$ & $\begin{array}{l}\text { Other studies on landfill site selection used } \\
\text { the same criterion }\end{array}$ \\
\hline \multirow[t]{40}{*}{ Landfill suitability } & \multirow[t]{5}{*}{ Land elevation (m) } & $56-78$ & 1 & $\begin{array}{l}\text { Ali and Ahmad (2020), Şener et al. (2010, } \\
\text { 2011), Kontos et al. (2005) }\end{array}$ \\
\hline & & $79-87$ & 2 & \\
\hline & & $88-92$ & 3 & \\
\hline & & $93-101$ & 4 & \\
\hline & & $102-124$ & 5 & \\
\hline & \multirow[t]{5}{*}{ Slope $\left({ }^{\circ}\right)$} & $0-17$ & 1 & $\begin{array}{l}\text { Ali and Ahmad (2020), Aziz and Khoda- } \\
\text { karami (2013), Ebistu and Minale (2013), } \\
\text { Guiqin et al. (2009) }\end{array}$ \\
\hline & & $18-35$ & 2 & \\
\hline & & $36-53$ & 3 & \\
\hline & & $54-71$ & 4 & \\
\hline & & $72-89$ & 5 & \\
\hline & \multirow[t]{4}{*}{ Soil } & Clay loam to clay & 1 & Şener et al. (2011, Sumathi et al. (2008) \\
\hline & & Clayey skeletal & 2 & \\
\hline & & Sandy clay loam to clay & 3 & \\
\hline & & Sandy clay loam to clay & 4 & \\
\hline & \multirow[t]{3}{*}{ Geological structure } & Panchet & 1 & Şener et al. (2011) \\
\hline & & Laterite & 2 & \\
\hline & & Alluvium & 3 & \\
\hline & \multirow[t]{8}{*}{ Land use land cover } & Built-up & 8 & $\begin{array}{l}\text { Ali and Ahmad (2020), Aziz and Khoda- } \\
\text { karami (2013), Gorsevski et al. (2012), } \\
\text { Serwan and Flannagan (1998) }\end{array}$ \\
\hline & & Settlement & 7 & \\
\hline & & Industrial zone & 6 & \\
\hline & & Swamp land & 5 & \\
\hline & & Sparse vegetation & 4 & \\
\hline & & Fallow land with vegetation & 3 & \\
\hline & & Green space with vegetation & 2 & \\
\hline & & Barren land & 1 & \\
\hline & \multirow[t]{5}{*}{ Distance to surface water (m) } & $<200$ & 5 & $\begin{array}{l}\text { Ali and Ahmad (2020), Chang et al. (2008), } \\
\text { Gorsevski et al. (2012), Ebistu and Minale } \\
\text { (2013), Jaybhaye et al. (2014) }\end{array}$ \\
\hline & & $201-400$ & 4 & \\
\hline & & $401-600$ & 3 & \\
\hline & & $601-800$ & 2 & \\
\hline & & $>800$ & 1 & \\
\hline & \multirow[t]{5}{*}{ Distance to tube wells and wells } & $<100$ & 5 & $\begin{array}{l}\text { Al-Jarrah and Abu-Qdais (2006), Uyan } \\
\text { (2013) }\end{array}$ \\
\hline & & $101-200$ & 4 & \\
\hline & & $201-300$ & 3 & \\
\hline & & $301-400$ & 2 & \\
\hline & & $>400$ & 1 & \\
\hline & \multirow[t]{5}{*}{ Distance to roads (m) } & $<100$ & 1 & $\begin{array}{l}\text { Ali and Ahmad (2020), Donevska et al. } \\
\text { (2012), Guiqin et al. (2009), Guler and } \\
\text { Yomralioglu (2017) }\end{array}$ \\
\hline & & $101-200$ & 2 & \\
\hline & & $201-300$ & 3 & \\
\hline & & $301-400$ & 4 & \\
\hline & & $>400$ & 5 & \\
\hline
\end{tabular}


Table 2 (continued)

\begin{tabular}{|c|c|c|c|c|}
\hline Goal & Criterion & Sub-criteria/alternatives & $\begin{array}{l}\text { Suitability } \\
\text { index (rank- } \\
\text { ing) }\end{array}$ & $\begin{array}{l}\text { Other studies on landfill site selection used } \\
\text { the same criterion }\end{array}$ \\
\hline & \multirow[t]{5}{*}{ Distance to industrial belts (m) } & $<500$ & 5 & \multirow[t]{5}{*}{ Pasalari et al. (2019) } \\
\hline & & $501-1000$ & 4 & \\
\hline & & $1001-1500$ & 3 & \\
\hline & & $1501-2000$ & 2 & \\
\hline & & $>2000$ & 1 & \\
\hline & \multirow[t]{5}{*}{ Distance to sensitive places (m) } & $<500$ & 5 & \multirow[t]{10}{*}{$\begin{array}{l}\text { Ali and Ahmad (2020), Guler and Yomrali- } \\
\text { oglu (2017), Kontos et al. (2005) }\end{array}$} \\
\hline & & $501-1000$ & 4 & \\
\hline & & $1001-1500$ & 3 & \\
\hline & & $1501-2000$ & 2 & \\
\hline & & $>2000$ & 1 & \\
\hline & \multirow[t]{5}{*}{ Land cost value (lakh) } & $2.25-4.84$ & 1 & \\
\hline & & $4.85-6.24$ & 2 & \\
\hline & & $6.25-8.84$ & 3 & \\
\hline & & $8.85-13.74$ & 4 & \\
\hline & & $13.75-23.00$ & 5 & \\
\hline
\end{tabular}

(Şener et al. 2010, b) as there is an inverse relationship between the landfill site suitability and the height of land (Kontos et al. 2005). An elevation map was prepared with Triangular Irregular Network (TIN) using Arc GIS analyst tool. The elevation of the study area ranges from 56 to $124 \mathrm{~m}$ from MSL. Five different buffer zones were prepared and given rank value according to the height for landfill site selection. The buffer zone with an elevation between 56-78 $\mathrm{m}$ was considered as highly suitable areas and ranked of 1 and the heights between 79-87, 88-92, 93-101, and 102-124 m were ranked as 2, 3, and 4, respectively, and considered as least preferable areas for landfill construction (Fig. 3a).

\subsubsection{Slope}

Land morphology of any area is estimated by slope gradation that is measured in percent or degree (Aziz and Khodakarami 2013). Higher degree slope is technically unsuitable

Table 3 Different constraints areas

\begin{tabular}{lll}
\hline S. no. & Constraints & $\begin{array}{l}\text { Buffer from } \\
\text { specific feature } \\
(\mathrm{m})\end{array}$ \\
\hline 1 & Buffer of industrial belts & 500 \\
2 & Buffer of roads & 100 \\
3 & Buffer of sensitive places & 500 \\
4 & Buffer of surface water bodies & 200 \\
5 & Buffer of tube wells and wells & 100 \\
\hline
\end{tabular}

for landfill establishment as the area with a steep slope is attributed to the migration of leachate in adding to contamination of water and soil (Ebistu and Minale 2013; Ali and Ahmad 2020) and economically infeasible for landfill construction (Guiqin et al. 2009). The slope layer map was prepared based on the SRTM DEM data of the study area using GIS environment with a scale of 1:250,000. The slope of the study area varies from $>1^{\circ}$ to $89^{\circ}$ and reclassified into very steep areas $\left(72^{\circ}-89^{\circ}\right)$, the steep areas $\left(54^{\circ}-71^{\circ}\right)$, moderate areas $\left(35^{\circ}-53^{\circ}\right)$, slightly slope areas $\left(18^{\circ}-35^{\circ}\right)$, and plane areas $\left(0^{\circ}-17^{\circ}\right)$ and given rank of $5,4,3,2,1$, respectively (Table 2). The most suitable areas were considered to be the plane areas with the rank of 1 (Fig. 3b) as the area with less than $17^{\circ}$ slope is thought to be extremely suitable for sanitary landfill site and the areas with more than $17^{\circ}$ slope are considered as unsuitable.

\subsubsection{Soil}

Soil classification is based on the report by the National Bureau of Land and Soil Survey (NBLSR), India. The soil map was prepared in a GIS environment with a scale of $1: 250,000$. The ranking of this sub-criterion is shown in Table 2. Scientific solid waste disposal sites should have a solid cover of low permeability drift such as boulder clay overlying low permeability bedrock, and a thick unsaturated zone (Daly 1983). Clay loam to clay is considered as best suitable site and received the highest rank for low porosity and impermeability (Şener et al. 2011). Followed by clay loam to clay other soils type, i.e., clayey skeletal, 
Fig. 2 Flow chart showing methodology applied in the present study

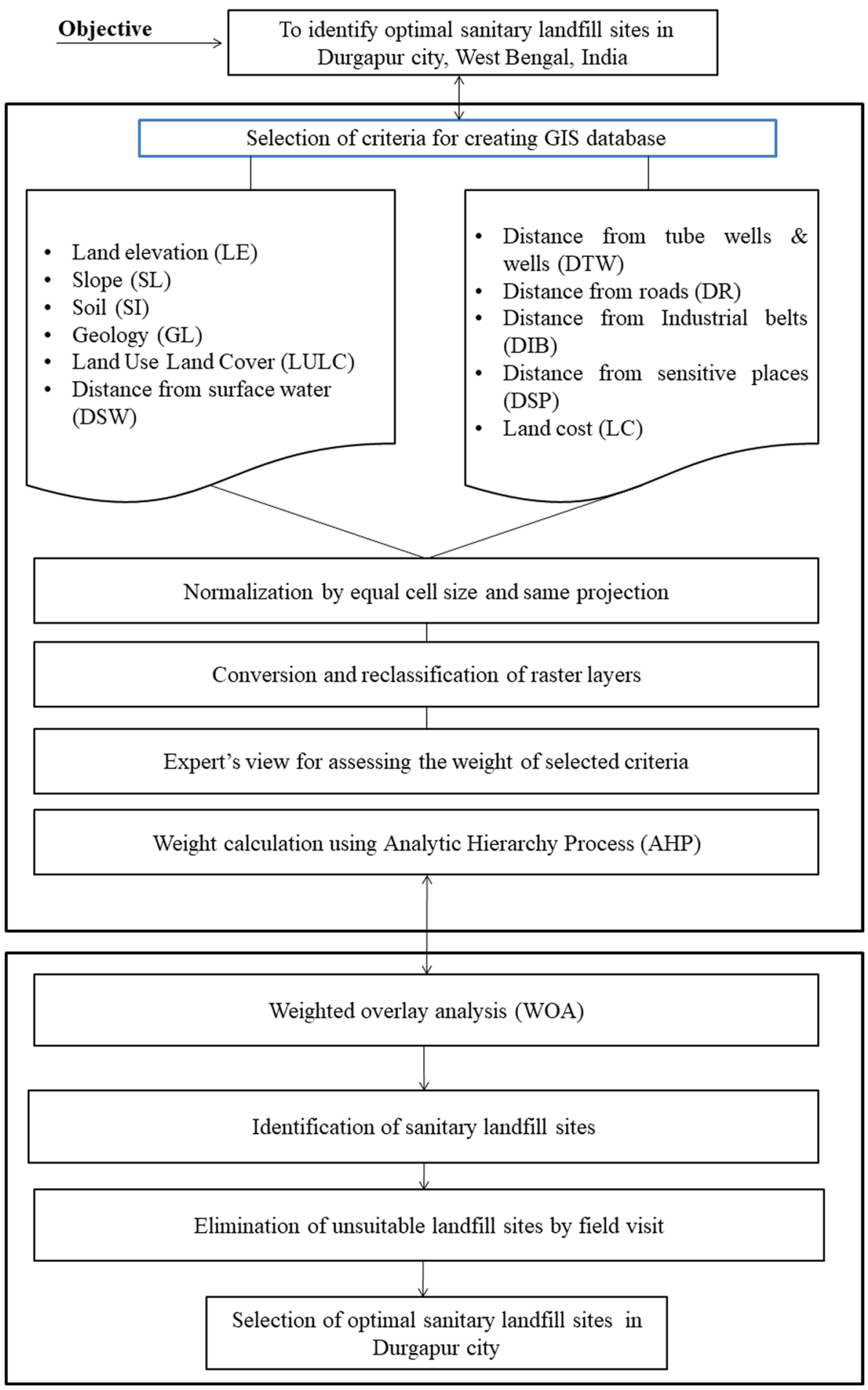

sandy clay loam to clay, and sandy clay loam to clay, have been considered as unsuitable for landfill site selection due to its high porosity, high infiltration rate (Sumathi et al. 2008) and moderated-to-heavy texture as the leachate may easily migrate and penetrate into the ground water (Fig. 3c).

\subsubsection{Geological Structure}

The geological structure plays an important role in the selection of landfill sites (Daly and Wright 1982). Geological structure categorization is based on the report by Geological Survey of India (GSI), India. The geological formations map of Durgapur was prepared in a GIS 
environment with a scale of 1:250,000. The ranking of this sub-criterion is shown in Table 2. The study area is comprised of three formations of geology including panchet, laterite, and alluvium. Most of the part of the study area is occupied by the alluvium deposits attributed with deep soil with high potential for water adsorption as the alluvium is composed of materials such as silt, sand, and gravel and identified as the most unsuitable unit (Şener et al. 2011). In this study, panchet formation was ranked as 1, laterite 2, and alluvium as 3 for landfill site suitability (Fig. 3d).

\subsubsection{Land Use Land Cover (LULC)}

In this study, the LULC map covers the areas of built-up, settlement, industrial zone, swampland, sparse vegetation, fallow land with vegetation, green space with vegetation and barren land. The high-resolution imagery (Sentinal-2 with $10 \mathrm{~m}$ resolution) was exploited for land use classification. The signature of land features was collected and supervised classification used. From the economic point of view, barren lands would be better, because these lands can be sold after the completion of the landfill (Aziz and Khodakarami 2013) and less resistance to public perspective (Serwan and Flannagan 1998; Gorsevski et al., 2012). Barren land was assigned as highly suitable areas for candidate landfill site establishment in the study area and ranked as 1 and built-up and settlement areas were considered as unsuitable as the residential areas can be adversely affected due to odor, dust, and noise from landfill site (Uyan 2013) (Fig. 3e).

\subsubsection{Surface Water Bodies}

Surface water is an inevitable parameter for landfill establishment to prevent the environmental and economic concerns, because it is responsible for major causes of the proliferation of diseases and surface water pollution (Gorsevski et al. 2012; Motlagh and Sayadi 2015); hence, it may necessitate an efficient drainage system with high expenses. The minimum distance between landfill and surface water bodies should be considered for checking contamination of water from landfill leachate (Şener et al. 2010, 2011; Mahvi et al. 2012; Luo et al. 2019; Pasalari et al. 2019). The existing literatures based on landfill site selection considered the distance varied from 100 to $300 \mathrm{~m}$ for surface water like ponds, lakes (Chang et al. 2008; Gorsevski et al. 2012; Ebistu and Minale 2013; CPHEEO 2016), canal (Jaybhaye et al. 2014), river (Gemitzi et al. 2006; Akbari et al. 2008; Ebistu and Minale 2013; Gorsevski et al. 2012). In the present study, considering the hydrological profile of the study area, important criteria, i.e., water bodies (e.g., ponds, lakes), canals, and river opted for proximate analysis. The input layers of selected criteria related to hydrology were extracted from
Fig. 3 a Landfill site suitability criteria-land elevation. b Landfill site suitability criteria-slope. c Landfill site suitability criteria-soil. d Landfill site suitability criteria-geological structure. e Landfill site suitability criteria-land use land cover (LULC). f Landfill site suitability criteria-distance to surface water. $\mathbf{g}$ Landfill site suitability criteria-distance to tube wells and wells. h Landfill site suitability criteria-distance to roads. i Landfill site suitability criteria-distance to industrial belts. $\mathbf{j}$ Landfill site suitability criteria-distance to sensitive places. k Landfill site suitability criteria-land cost value

Google earth pro-open software. The vector layer of each criterion was first created and exported in a GIS environment for proximate analysis. According to the landfill siting rules of MSWM, India, less than 200-m areas were rejected and five buffer zones equal to $200 \mathrm{~m}$ were considered around surface water bodies, e.g., ponds, lake, canal, river, and other water sources in the study area. These vector layers were converted into a raster layer (V2R) and reclassified with a scale value of $1-5$. Here, five indicates the least suitable areas attributed with $<200 \mathrm{~m}$ areas and one indicates highly suitable areas for municipal landfill sites with $>800 \mathrm{~m}$ buffer zone (Fig. 3f).

\subsubsection{Distance to Tube Wells and Wells}

A landfill site should be located away from any surface streams, lakes, rivers, wells or wetlands, because landfills generate leachate and noxious gases leading to adverse effects on wells water making them unsuitable (Al-Jarrah and Abu-Qdais 2006; Aziz and Khodakarami 2013; Uyan 2013). The locations of the tube wells and wells were collected by field visits with the help of GPS tool and $x, y$ coordinates were collected for spatial mapping. Distance between 0 and $100 \mathrm{~m}$ around tube wells and wells was considered as the most highly unsuitable area and received and less than $100 \mathrm{~m}$ areas have received the rank of 5. Five different buffer zones with $100 \mathrm{~m}$ intervals were constructed and $>400 \mathrm{~m}$ areas were considered highly suitable for landfill siting and ranked 1 (Fig. 3g).

\subsubsection{Distance to Roads}

In this study, suitable landfill sites were considered in the proximity to roads as the construction costs of building a new road infrastructure and transportation costs increases with increasing distances between the waste generation points and candidate landfill sites (Daly and Wright 1982; Guiqin et al. 2009; Donevska et al. 2012; Gorsevski et al. 2012; Das and Bhattacharyya 2015; Guler and Yomralioglu 2017). However, some research studies highly considered the landfill siting away from the road network for aesthetic and environmental concerns (Rafiee 2011; Jaybhaye et al. 2014). The input layers of the selected criteria related to roads were extracted from an open street map. These vector 
(a) Landfill site suitability criteria-Land elevation

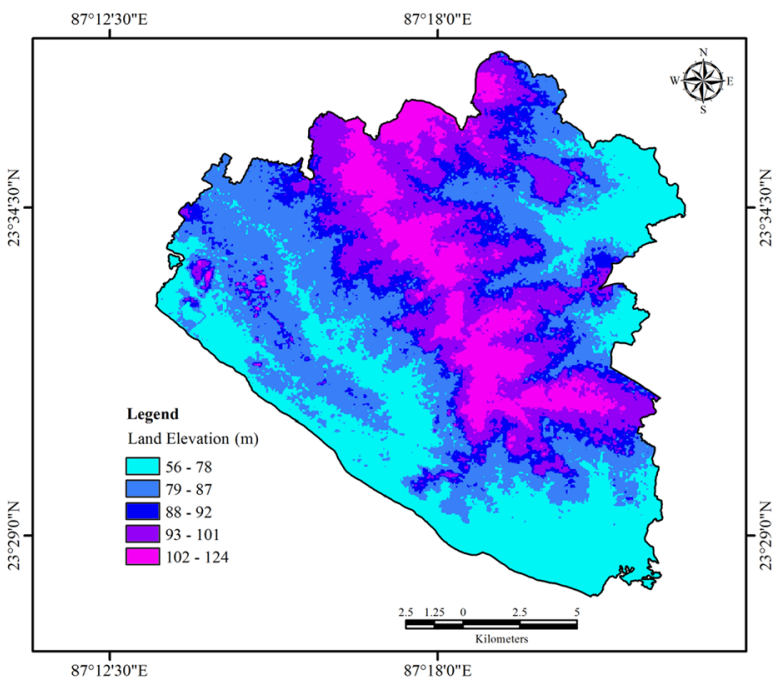

(b) Landfill site suitability criteria-Slope

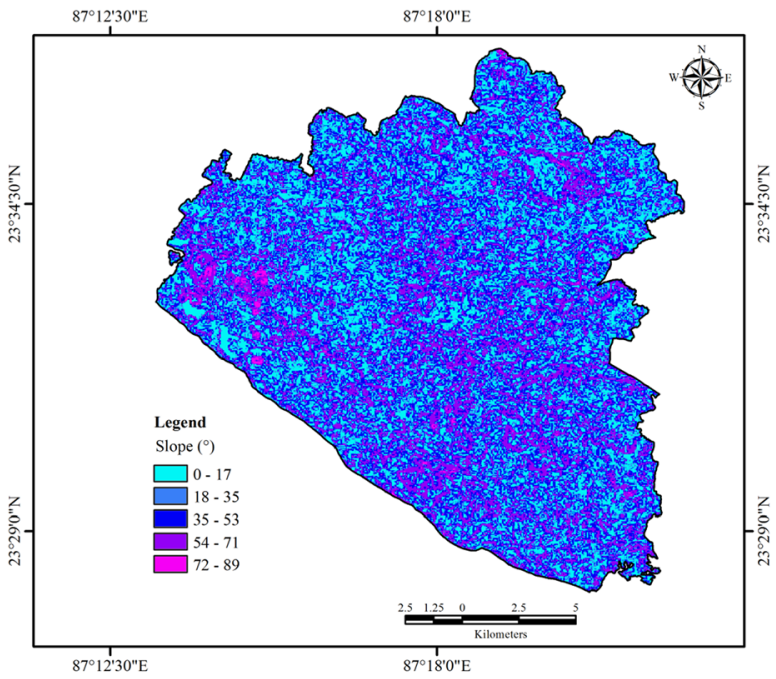

(c) Landfill site suitability criteria-Soil

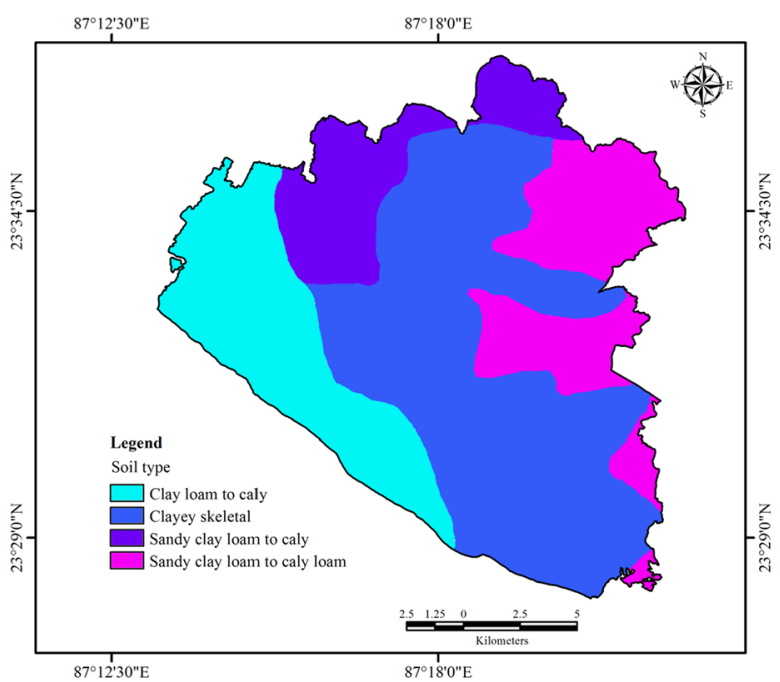

(d) Landfill site suitability criteria-Geological structure $8^{\circ} 12^{1} 30^{\circ} \mathrm{E}$ $87^{\circ} 180^{\circ} \mathrm{E}$

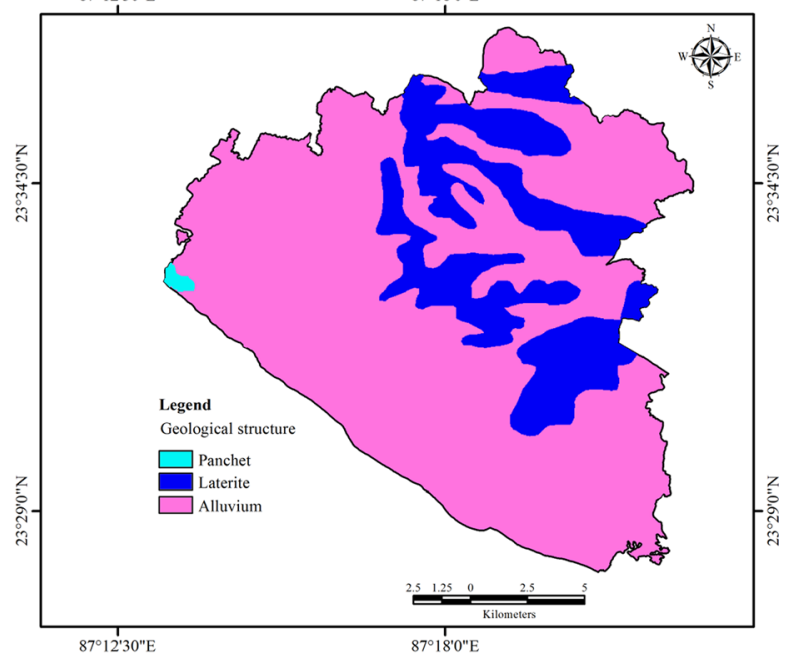

(e) Landfill site suitability criteria-Land Use Land Cover (LULC) $8^{\circ} 12^{\prime}: 30^{\prime \prime} \mathrm{E}$

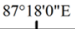

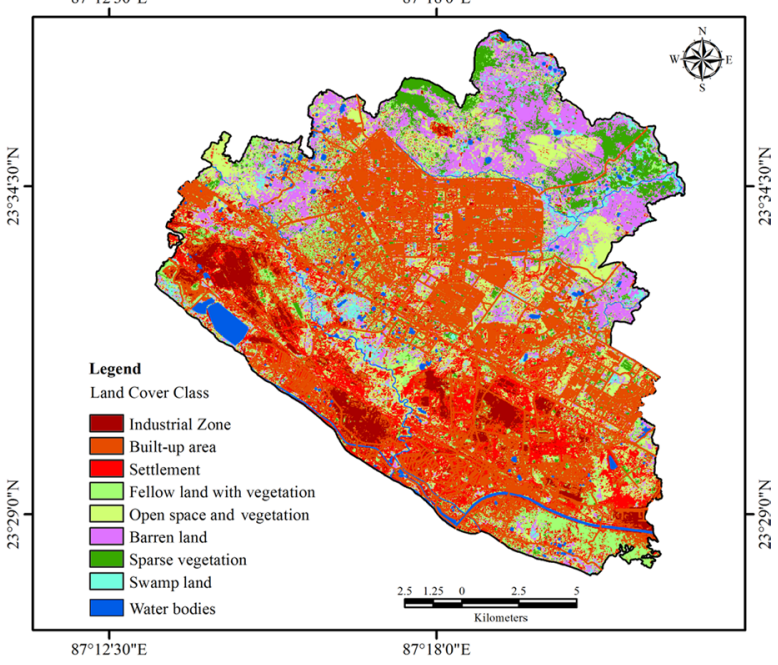

(f) Landfill site suitability criteria-Distance to surface water

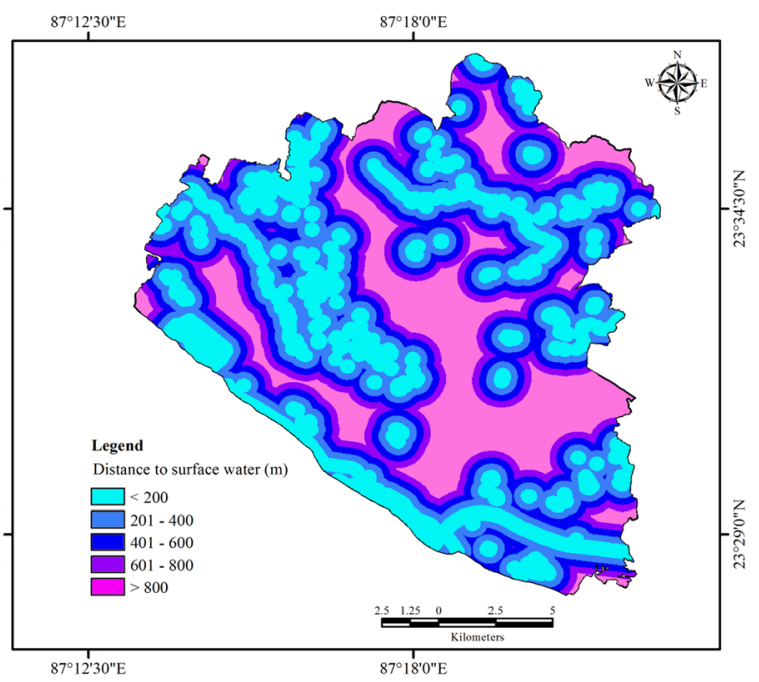


(g) Landfill site suitability criteria-Distance to tube wells and wells

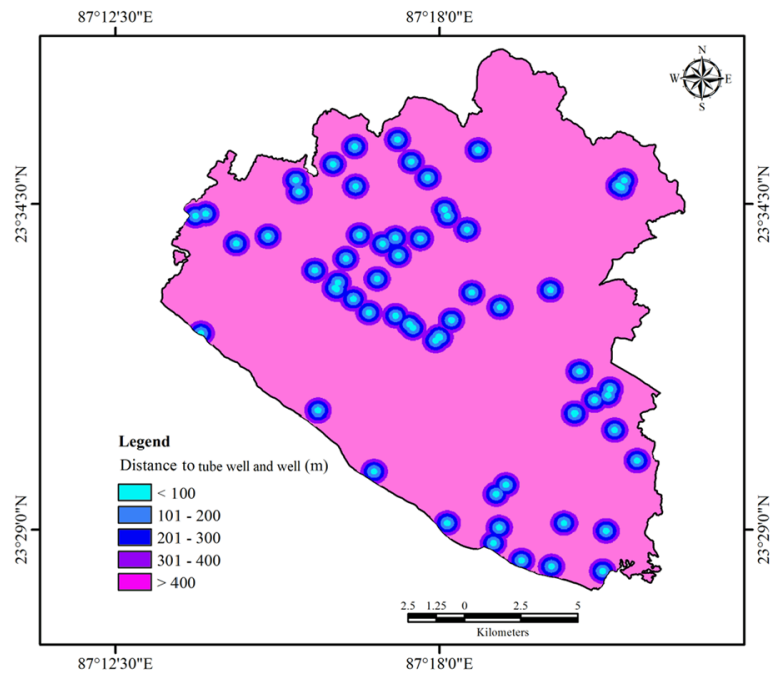

(h) Landfill site suitability criteria-Distance to roads

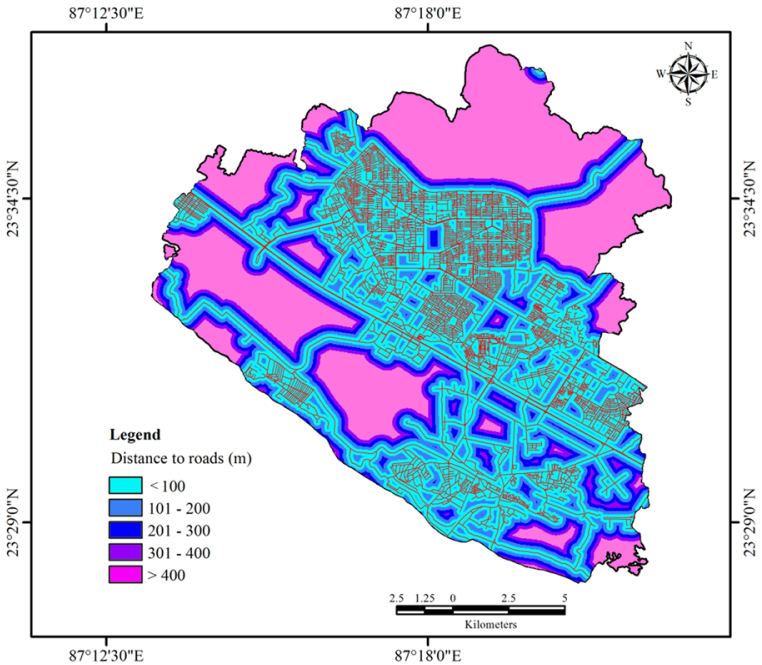

(i) Landfill site suitability criteria-Distance to industrial belts

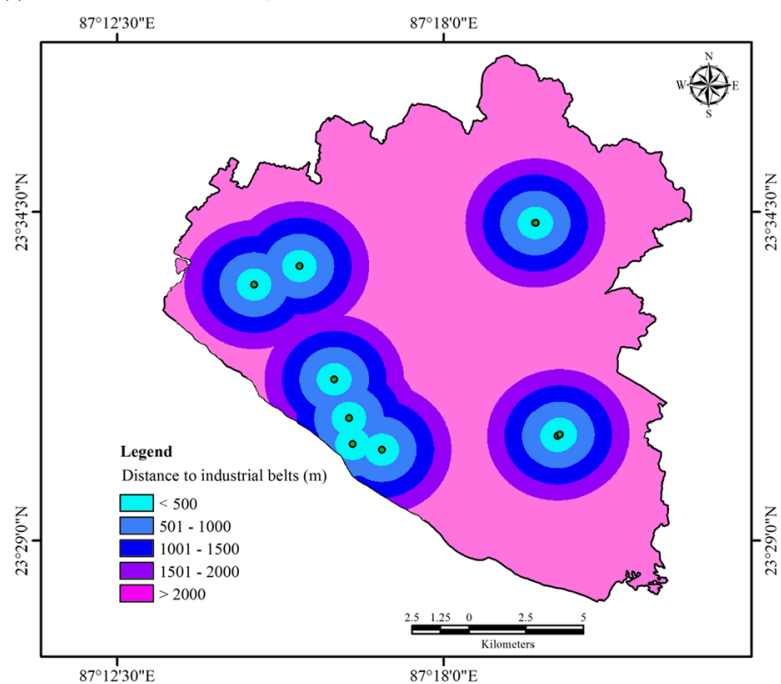

(j) Landfill site suitability criteria-Distance to sensitive places

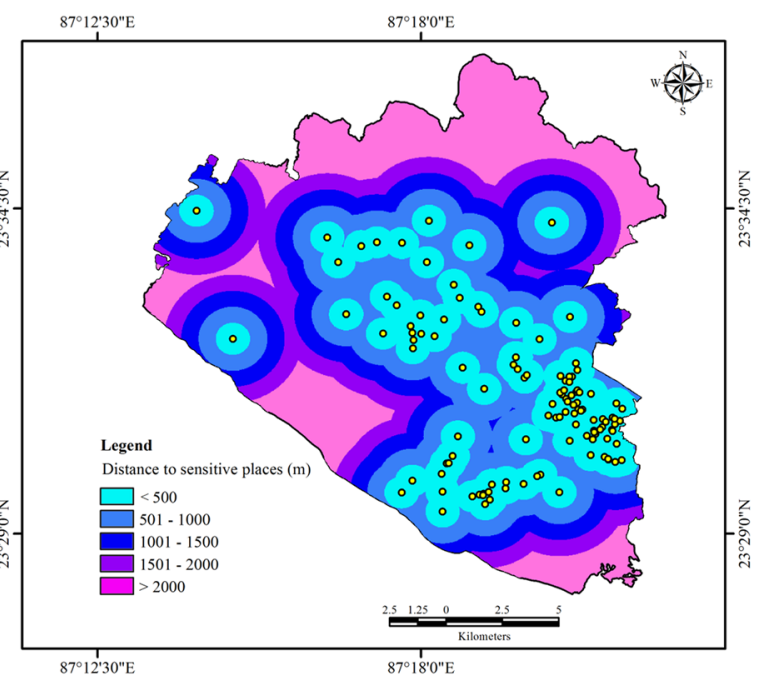

(k) Landfill site suitability criteria-Land cost value

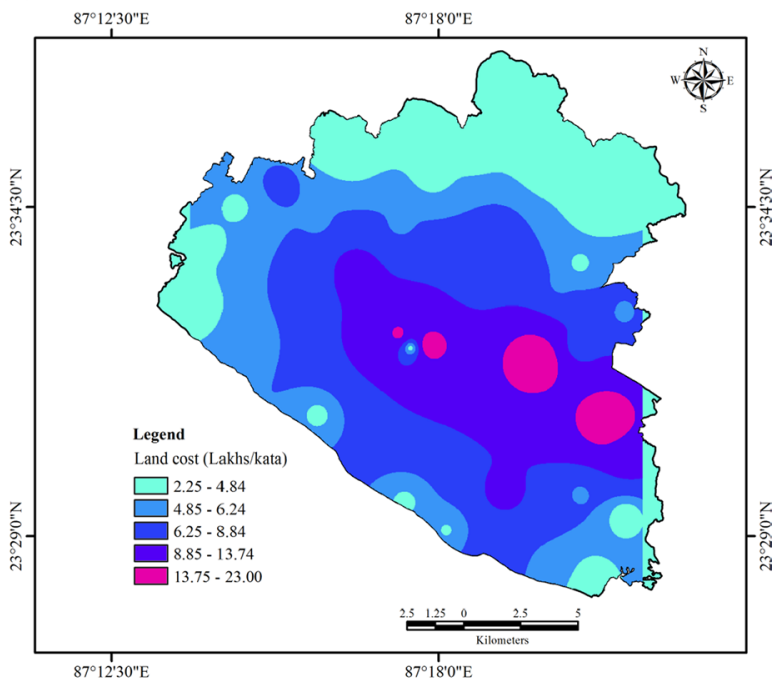

Fig. 3 (continued) 
layers were converted into a raster layer (V2R) and reclassified with a scale value of $1-5$. Areas with less than $100 \mathrm{~m}$ were received highly suitable and ranked as $1 .>400 \mathrm{~m}$ buffer zone was considered as least suitable for landfill site construction and ranked as 5 (Fig. 3h).

\subsubsection{Distance to Industrial Belt}

Consideration of industrial location is a crucial parameter for setting up of new landfill site, because disposal MSW into the industrial area is prohibited (Pasalari et al. 2019). Hence, industrial areas were considered as unsuitable for landfill sites. The input layers, i.e., industrial belts, were extracted from Google earth pro-open software. These vector layers were converted into a raster layer (V2R) and reclassified with a scale value of 1-5. Five different buffer zones with an interval of $500 \mathrm{~m}$ were prepared with GIS environment and the areas with less than $500 \mathrm{~m}$ were rejected as per the rules and regulation of Municipal Solid Waste Management, India. The areas with more than $2000 \mathrm{~m}$ distance from landfills were received as highly acceptable for landfill establishment and ranked of 1 (Fig. 3i).

\subsubsection{Distance to Sensitive Places}

Siting of new landfill site close to restricted and sensitive places is strictly prohibited due to its multifarious problems in the surrounding urban environment (Kontos et al. 2005; Guler and Yomralioglu 2017). In this study, sensitive places such as schools, colleges, universities, offices, institutions, banks, nursing homes, hospitals, health care centers, children's parks, and natural parks were considered for the construction of landfill sites. The input layers related to sensitive places were extracted from Google earth pro-open software. These vector layers were converted into a raster layer (V2R) and reclassified with a scale value of $1-5$. Five different buffer zones with an interval of $500 \mathrm{~m}$ were obtained using the GIS environment and the areas with less than $500 \mathrm{~m}$ were rejected as per the rules and regulation of the Municipal Solid Waste Management Act 2016, India. The areas with more than $2000 \mathrm{~m}$ distance from landfills were received as highly acceptable for landfill establishment (Fig. 3j).

\subsubsection{Land Cost}

The land cost value is an essential economic factor for the construction and operation of the landfill sites in any area. A GPS based field survey regarding the actual price of land in the study area was conducted and $x, y$ coordinates of different places were taken for spatial mapping. Personal discussions with the residents reveal that the land value varies from 2.25 lakhs to 23 lakhs per Katha ( 1 Katha $=0.00668$ ha) in the area. It is estimated that the land value in the study area is touching the skyscraper, so economic factors must be considered in the siting of the new landfill. Considering the ranges of land value five different buffer zones were prepared and the land with the least cost was considered as highly acceptable for landfill construction and ranked as of 1 . On the other hand, the lands with higher prices were considered unsuitable (Fig. 3k).

\subsection{Multi-criteria Technique: Analytic Hierarchy Process (AHP)}

AHP belongs to the multi-criteria-decision-making approach and most widely used technique, as it facilitates the users to select the best alternative among several possible choices (Saaty 1980; Eastman et al. 1995; Jankowski 1995; Uyan 2013; Maletič et al. 2016). In AHP, first of all, selected criteria are organized in a hierarchical structure depending on the general goal. From the practical point of view, AHP comprises several stages, like develop a decision model for selected criteria, derive their weights, and derive preferences for the criterion, derived overall priorities, and derived sensitivity for the final decision (Saaty 1980; Rezaei-Moghaddam and Karami 2007; Biswas et al. 2011).

There are different techniques of multi-criteria-decision-making approach like weighted sum model (WSM), weighted product model (WPM), weighted aggregated sum product assessment (WASPAS), technique for order preference by similarity to ideal solution (TOPSIS), analytic hierarchy process (AHP) etc. but AHP was widely used for landfill site selection (Chabuk et al. 2017; Gbanie et al. 2013; Guiqin et al. 2009; Guler and Yomralioglu 2017; Khan and Samadder 2015; Şener et al. 2011). In practical, the main drawback of AHP is the use of a crisp numeric value which is inadequate because of human judgment and ranking for comparison matrix may be personal biased and ambiguous (Ali and Ahmad 2020). But it tackles complex decision making problems in real situation and offer best result in comparison other MCDM techniques, especially while integrating with GIS and spatial data (Ali and Ahmad 2019a, b).

Therefore, AHP was used in present study as a multicriteria decision-making tool, combined with GIS for optimal landfill site selection in Durgapur city, West Bengal, India. As a whole, a structured hierarchy of decision making approach with AHP involves the following steps.

1. Firstly, define the problem that needs to solve

2. Structure a hierarchy of the criterion and sub-criteria looking towards the problem

3. Mention the rating of each criterion based on the significance level to each other

4. Calculate the weight against each criterion using numerical pair-wise comparison scale 
Table 4 Pairwise comparison matrix

\begin{tabular}{lllllllllllll}
\hline & LE & SL & SI & GL & LULC & DSW & DTW & DR & DIB & DSP & LC & Wi \\
\hline LE & 1 & 0.33 & 0.5 & 0.33 & 0.33 & 0.25 & 0.33 & 0.2 & 0.25 & 0.25 & 0.16 & 0.0222 \\
SL & 3 & 1 & 2 & 0.5 & 0.25 & 0.25 & 0.33 & 0.25 & 0.33 & 0.2 & 0.2 & 0.0351 \\
SI & 2 & 0.5 & 1 & 0.5 & 0.33 & 0.25 & 0.5 & 0.33 & 0.5 & 0.25 & 0.16 & 0.0314 \\
GL & 3 & 2 & 2 & 1 & 0.33 & 0.5 & 0.33 & 0.25 & 0.33 & 0.33 & 0.2 & 0.0433 \\
LULC & 3 & 4 & 3 & 3 & 1 & 0.25 & 0.25 & 0.33 & 0.33 & 0.5 & 0.25 & 0.0640 \\
DSW & 4 & 4 & 4 & 2 & 4 & 1 & 0.5 & 0.33 & 0.5 & 0.5 & 0.33 & 0.0880 \\
DTW & 3 & 3 & 2 & 3 & 4 & 2 & 1 & 0.25 & 0.33 & 0.5 & 0.25 & 0.0849 \\
DR & 5 & 4 & 3 & 4 & 3 & 3 & 4 & 1 & 0.5 & 0.33 & 0.25 & 0.1233 \\
DIB & 4 & 3 & 2 & 3 & 3 & 2 & 3 & 2 & 1 & 0.5 & 0.25 & 0.1137 \\
DSP & 4 & 5 & 4 & 3 & 2 & 2 & 2 & 3 & 2 & 1 & 0.33 & 0.1409 \\
LC & 6 & 5 & 6 & 5 & 4 & 3 & 4 & 4 & 4 & 3 & 1 & 0.2528 \\
\hline
\end{tabular}

$\lambda_{\max }=12.320 ; \mathrm{CI}=0.132 ; \mathrm{RI}=1.51 ; \mathrm{CR}=0.087$, i.e., $\leq 0.1$

$L E$ land elevation, $S L$ slope, $S I$ soil, $G L$ geology, $L U L C$ land use land cover, $D S W$ distance to surface water, $D T W$ distance to tube wells, $D R$ distance to roads, $D I B$ distance to industrial belts, $D S P$ distance to sensitive places, $L C$ land cost
5. Analyze the maximum eigenvalue, consistency index (CI), consistency ratio (CR), and normalized values for each criterion

6. And finally, if the value of CR (Consistency ratio)is insignificant, i.e., $>0.1$, then the pairwise comparison would be considered as inconsistent and should be repeated the experts' opinion to make it consistent (Saaty 1980; Lee and Chan 2008; Ali and Ahmad 2018).

For AHP, initially, a hierarchy was developed for decision criteria, i.e., selection of optimal landfill sites. Then, the hierarchy is constituted by the selected criteria to reach a certain goal. In the present study, eleven criteria were selected viz. land elevation (LE), slope (SL), soil (SI), geology (GL), land use land cover (LULC), distance to surface water (DSW), distance to tube wells (DTW), distance to roads (DR), distance to industrial belts (DIB), distance to sensitive places (DSP), and land cost (LC).

Consequently, the pairwise comparison matrix (PCM) was established to give relative importance to the criteria (Table 4). The comparison matrix is shown in the following equation:

$$
\begin{aligned}
& C_{1} C_{2} \quad C_{n}
\end{aligned}
$$

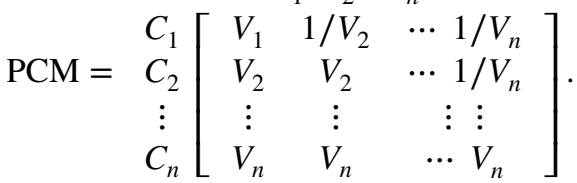

The numerical values to give the relative importance to the criteria was adopted from Saaty's Pair-wise Comparison Scale which ranging from 1 to 9 (Table 5). In the present study, six experts were invited who have well knowledge to fill a blank table (same as Table 4) for giving rank to
Table 5 Pair-wise comparison scale (adopted from Saaty 1980)

\begin{tabular}{ll}
\hline Verbal judgment & $\begin{array}{l}\text { Numeric } \\
\text { value }\end{array}$ \\
\hline Extremely important & 9 \\
Very strongly more important & 8 \\
& 7 \\
Strongly more important & 6 \\
Moderately more important & 5 \\
Equally important & 4 \\
\hline
\end{tabular}

a criterion with respect to other criteria using the scale as indicated in Table 5. After receiving the expert's view, the final rank was derived for each criterion using the following equation:

$\frac{\sum \mathrm{er}_{1}+\mathrm{er}_{2} \cdots+\mathrm{er}_{n}}{N}$,

where $\mathrm{er}_{1}$ is the rank given by expert $1, N$ is the total number of experts invited.

The rank of importance of one criterion to its next level will yield as the reciprocal relationship, i.e., 2 or 3 rank of one criterion will yield as $1 / 2$ or $1 / 3$. To find out the ranking priorities of each criterion, the normalize column sum (NCS) was computed which is expressed as

$$
\frac{C_{i}}{\sum C_{i}},
$$


where $C_{i}$ is the rank of ' $n$ ' criteria, and $\sum C_{i}$ is the sum of ' $n$ ' criteria.

After computing the NCS, the weight was calculated using the following equation:

$W_{i}=\frac{C_{1}+C_{2}+C_{3}+C_{4} \cdots C_{n}}{N}$,

where $W_{i}$ is the weight of criteria; $C_{1}+C_{2}+C_{3}+C_{4} \cdots C_{n}$ is the NCS of each criteria, and $N$ is the total no. of criteria.

It is essential to cheek the consistency of the result, i.e., the derived weight. Thus, the consistency ratio (CR) of the PCM is required to calculate. If the CR exceeds ' 0.1 ', the set of decision is considered as inconsistent and it has to repeat again; if CR is absolutely ' 0 ', it means the decision is perfectly consistent (Saaty 1990, 2012). The CR is expressed as

$\mathrm{CR}=\frac{\mathrm{CI}}{\mathrm{RI}}$,

where $\mathrm{CR}$ is the consistency ratio, $\mathrm{CI}$ is the consistency index and RI is the random index. For RI, the index table given by Saaty was used (Table 6). Whereas, the consistency index is calculated by putting the following equation:

$\mathrm{CI}=\frac{\left(\lambda_{\max }-n\right)}{(n-1)}$,

where $\lambda_{\max }$ is the average of Eigen value, $n$ is the total number of selected criteria.

\subsection{Weighed Overlay Analysis (WOA)}

Weighted overlay function in GIS allows users to combine different spatial layers for the final result. It is a multi-parametric model that comes under one of the fundamental modules of the multi-criteria decision-making method which follows the compensatory combination rules. This technique has successfully applied in different studies and analysis viz. landfill site selection (Mahini and Gholamalifard 2006; Hussin et al. 2010), land-use suitability analysis (Heywood et al. 1995; Jankowski 1995; Beedasy and Whyatt 1999; Barredo et al. 2000; Malczewski 2004), diseases susceptibility (Ali and Ahmad 2018, 2019a, b); soil erosion (Pal 2015; Ghosh and Lepcha 2018) and many other studies. In the present study, the weighted overlay analysis (WOA) was used to identify the optimal and suitable sites for landfill selection based on the weights calculated through AHP. All the selected criteria in the raster format were reclassified into equal cell size and combined them into a single suitability layer. The WOA is defined as

$\mathrm{WOA}=\sum_{i=1}^{n} W_{i} \times R_{i}$ where $W_{i}$ is the weight of particular decision criteria, $C_{i}, R_{i}$ is the raster layer of the same criteria, $n$ is the number of decision criteria.

\section{Results and Discussion}

In the present study, eleven criteria encompassing environmental and economic aspects were determined based on the study area problems and each criteria map was designed using the GIS environment with weight values calculated as per AHP methodology and combined for landfill suitability map by the Land Suitability Index. The evaluation of selected criteria was performed as per the MSWM Rules, 2016, India and published works of literature. Based on the selected criteria such as geology, soil, tube wells \& wells, land-use land cover, surface water bodies, roads, land cost value, industrial belts, sensitive places, slope and elevation, three candidate sites have been chosen for solid waste landfill in the study area due to highest landfill suitability analyzed by the GIS and AHP techniques. The criteria maps were prepared using a 1:250,000 scale map. Used GIS techniques are buffer zoning, interpolation, and overlay analysis. In the first level of analysis, a set of 12 potential sites were identified but subsequent screening and refinement on the basis of existing factors in the study area; three best-fitted sites were extracted. For taking the final decision, field observation of the most preferable landfill sites in the study area was carried out as the importance of field visits have been accentuated in many kinds of research (e.g., Nas et al. 2010; Eskandari et al. 2012) to verify the ground reality.

The AHP technique was used to determine the significance of each selected criteria and to determine the weightage of the criteria. As per the result of AHP as shown in Table 8, the criteria of land cost received highest weightage value (25\%). The land cost value in DMC areas can play key role in considering a potential site for waste disposal as the land cost value is increasing day by day due to rapid urban expansion and population growth. Followed by land cost, the sensitive places (14\%) and roads (12\%) gained second and third rank, respectively. The other criteria in descending order as per their rank are distance to industrial belts, surface water bodies, tube wells, LULC, slope, geology and land elevation.

At the end of the analysis, a landfill site suitability map was prepared using eleven criteria layers in a GIS environment for the optimal and sustainable location of municipal landfills in Durgapur city. The site suitability map shows three highly suitable sites that lie in the northern parts of city spreading over the barren land and sparsely vegetation. The three candidate sites, i.e., S1, S2, and S3 (Fig. $4 \mathrm{a}, \mathrm{b}$ ), were identified considering the transportation 
Table 6 Random index (adopted from Saaty 1990)

\begin{tabular}{ll}
\hline Numeric value & RI \\
\hline 2 & 0.00 \\
3 & 0.58 \\
4 & 0.90 \\
5 & 1.12 \\
6 & 1.24 \\
7 & 1.32 \\
8 & 1.41 \\
9 & 1.45 \\
10 & 1.49 \\
11 & 1.51 \\
12 & 1.53 \\
13 & 1.56 \\
14 & 1.57 \\
15 & 1.59 \\
\hline
\end{tabular}

cost, roads, land value, use of land, settlement and surface water bodies and other selected criteria. The sites $\mathrm{S} 1, \mathrm{~S} 2, \mathrm{~S} 3$ cover the areas of $13.83854,33.80678$, and 27.20085 ha, respectively (Table 7). The map (Fig. 4a, b) indicates that the site- 1 with 13.83854 ha area is located close to the northernmost boundary of the city which was far away from the city center. This site can be considered as the best suitable site for MSW disposal as it is inherent with barren land, low land cost value, absence of water bodies, vegetation and well connected with roads. The site-2 dominated the other sites due to its large size covering of 33.80678 ha area. This site can be considered another best-fitted site due to its closeness to the main settlement and well connected with road highway. The third most potential site (27.20085 ha) is located in the northeast part of the city inherited with low land cost value, barren land, away from the settlement, sensitive places, industrial zone, and water bodies but lacking connection of road network. Other 9 sites out of 12 identified sites were eliminated as they are situated in the high settlement, built-up areas, sandy soil with high infiltration rate or close to water bodies, dense vegetation, industrial zones, main roads, and high land cost values. The areas with high potential and optimal sanitary landfill sites are shown in green color and the areas with very least suitability sites have been highlighted in dark brown (Fig. 4a, b).

\section{Conclusion}

Rapid population growth, changing lifestyle and consumption pattern in Durgapur produce enormous quantities of MSW which has been a herculean task to manage efficiently by DMC due to increasing land cost value, low budget and traditional practice of waste disposal. The recommended
GIS-based site suitability model discussed in the current study will help the researchers, town planners, decision makers, civil engineers and government authorities to identify optimal sites for scientific landfill to maintain the sustainability of waste management and to protect the public health from ambient air, contamination of water, foul smells and toxic gasses released from burning waste. Durgapur, being an industrial town, is already facing several public health issues due to the emission of carbon dioxides $\left(\mathrm{CO}_{2}\right), \mathrm{NO}_{2}$, $\mathrm{SO}_{2}$ and discharge of gigantic amount of industrial effluents from different heavy industries. The present study has been considered as a fast rational decision-making process concerning the final disposal of MSW for the sake of better public health and environmental sustainability.

In this study, different data on the basis of selected criteria that are appropriate to the specific area were collected and prepared a suitability map in a GIS environment using widely accepted WOA. The analytical hierarchy process (AHP) was used to calculate weight and overlay analysis for best site selection. The technique also identified the potential environmentally risk prone areas and considered as unfitted for site selection. Three potential site alternatives for the sanitary landfill for Durgapur city were identified. The result found that land cost value was the most significant criterion in the model with a weight of 0.25258 . Followed by land cost value, sensitive places and roads were the second and third important criteria with a weight value of 0.1409 and 0.1233 , respectively (Table 8). The present work offers a scientific base for the study area, because still, there is no such multi-criteria based site suitability analysis carried out in the defined study area.

The paper emphasizes the integration of GIS and AHP in establishing the potential sites for landfill. GIS offers a more sophisticated process of spatial analysis and clear presentation of potentially suitable and unsuitable sites based on selected criteria. The weighting value of a selection criterion can vary for a country or a region. In DMC, the land cost was most expensive and given highest weighting value for the selection of alternatives site. Landfill site could not be opted, where the land cost value was high rather the land with low cost value was considered. From economical point of view, the suitable landfill sites were considered in the proximity to roads as the construction costs of building a new road infrastructure and transportation costs increases with increasing distances between the waste generation points and candidate landfill sites. Concerning the environmental aspect, landfill site selection has been opted away from surface water bodies. Hence, economic and environmental aspects were considered as the major criteria during the selection of alternatives. Therefore, consideration of knowledge from experts in various related fields such as engineers, geographers, soil scientists, geologists and economists is required to obtain reliable solutions for a new landfill siting process (Mat et al. 2016). In conclusion, the study recommends utilizing and applying such scientific work 
Fig. 4 Landfill suitability map a selected areas for sanitary landfill sites, b suitable landfill sites overlaid on land use
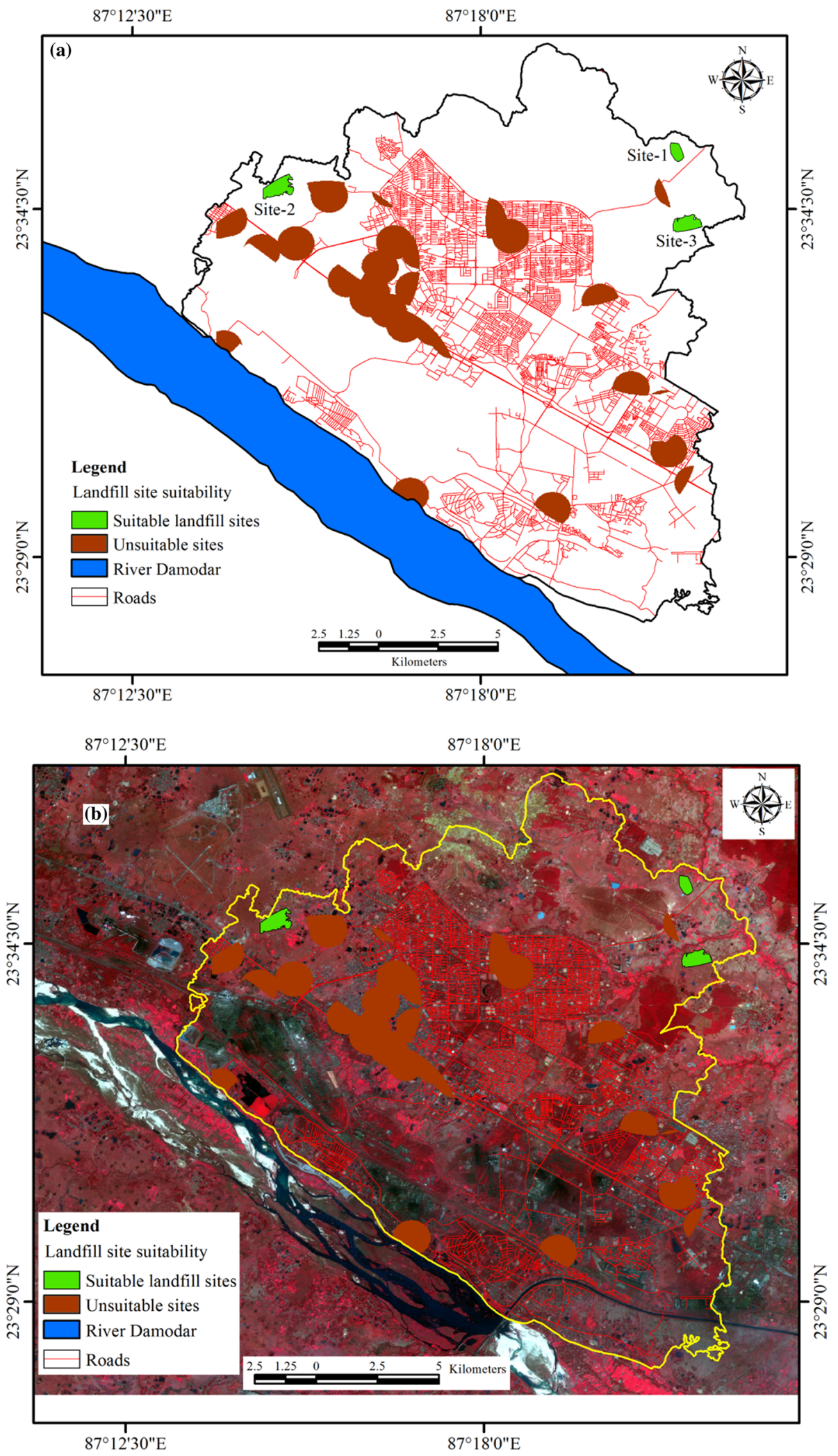
Table 7 Identified suitable sites for sanitary landfill

\begin{tabular}{|c|c|c|c|c|c|c|c|c|c|c|}
\hline Site no. & Description & the site & & & & & & & & Area (ha) \\
\hline Site-1 & $\begin{array}{l}\text { Barren land } \\
\text { and conne }\end{array}$ & $\begin{array}{l}\text { way from } \\
\text { on of roa }\end{array}$ & $\begin{array}{l}\text { ttlement, } \\
\text { Jays, land }\end{array}$ & $\begin{array}{l}\text { sitive places } \\
\text { vation and slc }\end{array}$ & $\begin{array}{l}\text { surface wat } \\
\text { is also com }\end{array}$ & $\begin{array}{l}\text { bodies, low } 1 \\
\text { atively lower }\end{array}$ & $\begin{array}{l}\text { cost valt } \\
\text { an the oth }\end{array}$ & $\begin{array}{l}\text { absence of } \\
\text { ites }\end{array}$ & etation & 13.83854 \\
\hline Site-2 & $\begin{array}{l}\text { Large area, } \\
\text { values, lar }\end{array}$ & $\begin{array}{l}\text { low land } \\
\text { elevation }\end{array}$ & $\begin{array}{l}\text { th sparse } \\
\text { id slope is }\end{array}$ & $\begin{array}{l}\text { etation, abse } \\
\text { o comparativ }\end{array}$ & $\begin{array}{l}\text { of water bo } \\
\text { lower than }\end{array}$ & $\begin{array}{l}\text { S and settlem } \\
\text { other sites, }\end{array}$ & $\begin{array}{l}\text {, sensitive } \\
\text { loam to }\end{array}$ & $\begin{array}{l}\text { aces and lo } \\
\text { soil optim }\end{array}$ & $\begin{array}{l}\text { and cost } \\
\text { for landfill }\end{array}$ & 33.80678 \\
\hline Site-3 & $\begin{array}{c}\text { Barren land } \\
\text { optimum }\end{array}$ & $\begin{array}{l}\text { way from } \\
\text { pe and la }\end{array}$ & $\begin{array}{l}\text { ttlement, } \\
\text { elevation }\end{array}$ & $\begin{array}{l}\text { sitive places, } \\
\text { landfill site }\end{array}$ & $\begin{array}{l}\text { lustrial zone } \\
\text { ction }\end{array}$ & ater bodies a & built-up a & s, low land & st value, & 27.20085 \\
\hline LE (\%) & SL (\%) & SI (\%) & GL (\%) & LULC (\%) & DSW (\%) & DTW (\%) & DR (\%) & DIB (\%) & $\operatorname{DSP}(\%)$ & $\mathrm{LC}(\%)$ \\
\hline 2.00 & 4.00 & 3.00 & 4.00 & 7.00 & 9.00 & 9.00 & 12.00 & 11.00 & 14.00 & 25.00 \\
\hline
\end{tabular}

$L E$ land elevation, $S L$ slope, $S I$ soil, $G L$ geology, $L U L C$ land use land cover, $D S W$ distance to surface water, $D T W$ distance to tube wells, $D R$ distance to roads, $D I B$ distance to industrial belts, $D S P$ distance to sensitive places, $L C$ land cost

in solving the landfill site selection problem for Durgapur city as well as the rapidly growing urban areas located at different corners of world which face the same problems.

Open Access This article is licensed under a Creative Commons Attribution 4.0 International License, which permits use, sharing, adaptation, distribution and reproduction in any medium or format, as long as you give appropriate credit to the original author(s) and the source, provide a link to the Creative Commons licence, and indicate if changes were made. The images or other third party material in this article are included in the article's Creative Commons licence, unless indicated otherwise in a credit line to the material. If material is not included in the article's Creative Commons licence and your intended use is not permitted by statutory regulation or exceeds the permitted use, you will need to obtain permission directly from the copyright holder. To view a copy of this licence, visit http://creativecommons.org/licenses/by/4.0/.

\section{References}

Abdul-Wahab SA (2004) Modeling methane and vinyl chloride in soil surrounding landfill. Int J Environ Pollut 21:339-349

Akbari V, Rajabi A, Shams R, Chavoshi SH (2008) Landfill site selection by combining GIS and fuzzy multi criteria decision analysis, case study: Bandar Abbas, Iran. World Appl Sci J 3:39-47

Ali SA, Ahmad A (2018) Using analytic hierarchy process with GIS for Dengue risk mapping in Kolkata Municipal Corporation, West Bengal, India. Spat Inf Res 26(4):449-469. https://doi. org/10.1007/s41324-018-0187-x

Ali SA, Ahmad A (2019a) Mapping of mosquito-borne diseases in Kolkata Municipal Corporation using GIS and AHP based decision making approach. Spat Inf Res. https://doi.org/10.1007/s4132 4-019-00242-8

Ali SA, Ahmad A (2019b) Spatial susceptibility analysis of vectorborne diseases in KMC using geospatial technique and MCDM approach. Model Earth Syst Environ. https://doi.org/10.1007/ s40808-019-00586-y

Ali SA, Ahmad A (2020) Suitability analysis for municipal landfill site selection using fuzzy analytic hierarchy process and geospatial technique. Environ Earth Sci 79:227. https://doi.org/10.1007/ s12665-020-08970-Z
Al-Jarrah O, Abu-Qdais H (2006) Municipal solid waste landfill siting using intelligent system. Waste Manag 26(3):299-306. https://doi. org/10.1016/j.wasman.2005.01.026

Allen A, Macarthy IAJ (1997) Geological aspects of waste disposal site selection. In: Proceedings of the 1st Irish environmental engineering conference, pp 233-239

Arkoc O (2014) Municipal solid waste landfill site selection using geographical information systems: a case study from Çorlu, Turkey. J Geosci 7(11):4975-4985. https://doi.org/10.1007/s1251 7-013-1107-y

Aziz RS, Khodakarami L (2013) Application of GIS models in site selection of waste disposal in an urban area. WIT Transactions on State-of-the-art in Science and Engineering 77(9):27-35

Banar M, Köse BM, Özkan A, Acar IP (2007) Choosing a municipal landfill site by analytic network process. Environ Geol 52:747-751

Barredo JI, Benavidesz A, Hervhl J, VanWesten CJ (2000) Comparing heuristic landslide hazard assessment techniques using GIS in the Tirajana basin, Gran Canaria Island, Spain. Int J Appl Earth Obs Geoinf 2(1):9-23. https://doi.org/10.1016/s0303-2434(00)85022 $-9$

Beedasy J, Whyatt D (1999) Diverting the tourists: a spatial decision support system for tourism planning on a developing island. Int J Appl Earth Obs Geoinf 1(3-4):163-174. https://doi.org/10.1016/ s0303-2434(99)85009-0

Biswas D, Biswas B, Mandal B, Banerjee A, Mukerjee TK, Nandi J (2011) Evaluating school students' perception about mosquitoes and mosquitoes-borne disease in the city of Kolkata, India. Dengue Bull 35:223-230

Chabuk AJ, Al-Ansari N, Hussain HM, Knutsson S, Pusch R (2017) GIS-based assessment of combined AHP and SAW methods for selecting suitable sites for landfill in Al-Musayiab Qadhaa, Babylon, Iraq. Environ Earth Sci 76:209. https://doi.org/10.1007/s1266 5-017-6524-x

Chandio IA, Matori ANB, WanYusof KB, Talpur MAH, Balogun AL, Lawal DU (2012) GIS-based analytic hierarchy process as a multicriteria decision analysis instrument: a review. Arab J Geosci 6(8):3059-3066. https://doi.org/10.1007/s12517-012-0568-8

Chang NB, Parvathinathan G, Breeden JB (2008) Combining GIS with fuzzy multicriteria decision-making for landfill siting in a fastgrowing urban region. J Environ Manag 87:139-153. https://doi. org/10.1016/J.JENVMAN.2007.01.011

Che Y, Yang K, Jin Y, Zhang W, Shang Z, Tai J (2013) Residents' concerns and attitudes toward a municipal solid waste landfill: 
integrating a questionnaire survey and GIS techniques. Environ Monit Assess 185:10001-10013

CPCB (2000) Management of municipal solid waste. Central Pollution Control Board, Delhi, http://www.cpcb.com. Accessed 3 Feb 2020

CPCB (2001) India States of the Environment, hazardous waste: special reference to municipal solid waste management, pp 133-149 http://cpcb.delhi.nic.in. Accessed 11 Sep 2019

CPHEEO (2016) Swachh Bharat Mission municipal solid waste management manual—Part I. Ministry of Urban Development. http:// cpheeo.gov.in/upload/uploadfiles/files/Part1(1).pdf. Accessed 12 Feb 2020

Daly D (1983) Co-disposal sites selection, investigation, and monitoring. In: Proceedings of seminar Local authority experience in implementation of water and waste legislation. Dun Laoghaire 16

Daly D, Wright GR (1982) Waste disposal sites. Geotechnical guidelines for their selection, design and management. Geol Surv Irel Inf Circ 82(1):50

Das S, Bhattacharyya BK (2015) Optimization of municipal solid waste collection and transportation route. Waste Manag 43:9-18. https ://doi.org/10.1016/j.wasman.2015.06.033

Delgado OB, Mendoza M, Granados EL, Geneletti D (2008) Analysis of land suitability for the siting of inter-municipal landfills in the Cuitzeo Lake Basin, Mexico. Waste Manag 28(7):1137-1146

Demesouka OE, Vavatsikos AP, Anagnostopoulos KP (2013) Suitability analysis for siting MSW landfills and its multicriteria spatial decision support system: method, implementation and case study. Waste Manag 33:1190-1206

Despotakis VK, Economopoulos AP (2007) A GIS model for landfill siting. Glob NEST J 9:29-34

Donevska K, Gorsevski P, Jovanovski M, Peshevski I (2012) Regional non-hazardous landfill site selection by integrating fuzzy logic, AHP and geographic information systems. Environ Earth Sci 67:121-131

Eastman JR, Weigen J, Kyem PAK, Toledano J (1995) Raster procedures for multi-criteria/multi-objective decisions. Photogramm Eng Remote Sens 61(5):539-547

Ebistu TA, Minale AS (2013) Solid waste dumping site suitability analysis using geographic information system (GIS) and remote sensing for Bahir Dar Town, North Western Ethiopia. Geospat Health 13(660):157-163

El-Fadel M, Findikakis AN, Leckie JO (1971) Environmental impact of solid waste-land filling. J Environ Manag 50:1-25

Eskandari M, Homaee M, Mahmodi S (2012) An integrated multi criteria approach for landfill siting in a conflicting environmental, economical and socio-cultural area. Waste Manag 32:1528-1538

Gbanie SP, Tengbe PB, Momoh JS, Medo J, Kabba VTS (2013) Modelling landfill location using geographic information systems (GIS) and multi-criteria decision analysis (MCDA): case study Bo, Southern Sierra Leone. Appl Geogr 36:3-12. https://doi. org/10.1016/j.apgeog.2012.06.013

Gemitzi A, Petalas C, Tsihrintzis VA, Pisinaras V (2006) Assessment of groundwater vulnerability to pollution: a combination of GIS, fuzzy logic and decision making techniques. Environ Geol 49:653-673

Geneletti D (2010) Combining stakeholder analysis and spatial multicriteria evaluation to select and rank inert landfill sites. Waste Manag 30:328-337

Ghosh P, Lepcha K (2018) Weighted linear combination method versus grid based overlay operation method-a study for potential soil erosion susceptibility analysis of Malda district (West Bengal) in India. Egypt J Remote Sens Space Sci. https://doi. org/10.1016/j.ejrs.2018.07.002

Gorsevski PV, Donevska KR, Mitrovski CD, Frizado JP (2012) Integrating multi-criteria evaluation techniques with geographic information systems for landfill site selection: a case study using ordered weighted average. Waste Manag 32:287-296. https:// doi.org/10.1016/j.wasman.2011.09.023

Guiqin W, Li Q, Guoxue L, Lijun C (2009) Landfill site selection using spatial information technologies and AHP: a case study in Beijing, China. J Environ Manag 90(8):2414-2421. https:// doi.org/10.1016/j.jenvman.2008.12.008

Guler D, Yomralioglu T (2017) Alternative suitable landfill site selection using analytic hierarchy process and geographic information systems: a case study in Istanbul. Environ Earth Sci 76:678. https://doi.org/10.1007/s12665-017-7039-1

Heywood I, Oliver J, Tomlinson S (1995) Building an exploratory multi-criteria modelling environment for spatial decision support. In: Fisher P (ed) Innovations in GIS. Taylor \& Francis, London

Hussin WMAW, Kabir S, Din MAM, Jaafar WZW (2010) Modeling landfill suitability based on multi-criteria decision making method. Interdisciplinary Themes J 20-30

IPCC (2014) Intergovernmental Panel on Climate Change (IPCC) assessment report (AR5). https://www.ipcc.ch/report/ar5/syr/. Accessed 23 Jan 2020

Jankowski P (1995) Integrating geographical information systems and multiple criteria decision making methods. Int J Geogr Inf Syst 9(3):251-273. https://doi.org/10.1080/02693799508902036

Jaybhaye R, Mundhe N, Dorik B (2014) Site suitability for urban solid waste disposal using geoinformatics: a case study of Pune Municipal Corporation, Maharashtra, India. Int J Adv Remote Sens GIS 3(1):769-783

Kara C, Doratli N (2012) Application of GIS/AHP in siting sanitary landfill: a case study in Northern Cyprus. Waste Manag Res 30:966-980. https://doi.org/10.1177/0734242X12453975

Khan D, Samadder SR (2015) A simplified multi-criteria evaluation model for landfill site ranking and selection based on AHP and GIS. J Environ Eng Lands Manag 23(4):267-278

Kim KR, Owens G (2010) Potential for enhanced phytoremediation of landfills using biosolids: a review. J Environ Manag 91(4):791-797

Klosterman RE (1995) The appropriateness of geographic information systems for regional planning in the developing world. Comput Environ Urban Syst 19:1-13

Kontos TD, Komilis DP, Halvadakis CP (2005) Siting MSW landfills with a spatial multiple criteria analysis methodology. Waste Manag 25:818-832

Lauber JD (2005) The burning issues of municipal solid waste disposal—what works and what doesn't. In: Toronto City Council municipal solid waste conference: advances in processes and programmes. http://www.jlauber.com. Accessed 10 Jan 2020

Lee GKL, Chan EHW (2008) The analytic hierarchy process (AHP) approach for assessment of urban renewal proposals. Soc Indic Res 89:55-168

Lotfi S, Habibi K, Koohsari MJ (2009) An analysis of urban land development using multi-criteria decision model and geographical information system (a case study of Babolsar City). Am J Environ Sci 5(1):87-93. https://doi.org/10.3844/ajessp.2009.87.93.

Luo H, Cheng Y, He D, Yang EH (2019) Review of leaching behavior of municipal solid waste incineration (MSWI) ash. Sci Total Environ 668:90-103

Mahvi AH, Roodbari AA, Nabizadeh Nodehi R, Nasseri S, Dehghani MH, Alimohammadi M (2012) Improvement of Landfill Leachate Biodegradability with Ultrasonic Process. E-Journal of Chemistry 7(7): e27571. https://doi.org/10.1371/journal.pone.0027571

Mahini AS, Gholamalifard M (2006) Siting MSW landfills with a weighted linear combination methodology in a GIS environment. Int J Environ Sci Technol 3(4):435-445. https://doi.org/10.1007/ BF03325953 
Malczewski J (2004) GIS-based land-use suitability analysis: a critical overview. Prog Plan 62(1):3-65. https://doi.org/10.1016/j.progr ess.2003.09.002

Malczewski J (2006) GIS-based multicriteria decision analysis: a survey of the literature. Int J Geogr Inf Sci 20:703-726

Maletič D, Lasrado F, Maletič M, Gomišček B (2016) Analytic hierarchy process application in different organisational settings. Applications and Theory of Analytic Hierarchy Process: Decision Making for Strategic Decisions 89, in Fabio De Felice, Thomas L. Saaty and Antonella Petrillo, IntechOpen. https://www.intechopen .com/books/applications-and-theory-of-analytic-hierarchy-proce ss-decision-making-for-strategic-decisions/analytic-hierarchyprocess-application-in-different-organisational-settings

Mat NA, Benjamin AM, Abdul-Rahman S, Wibowo A (2016) A framework for landfill site selection using geographic information systems and multi criteria decision making technique. In: AIP conference proceedings, vol 1782 (1), p 040011. https://doi. org/10.1063/1.4966078

MeBean EA, Rovers FA, Farquhar GJ (1995) Solid waste landfill engineering and design. Prentice Hall, Upper Saddle River, p 380

Motlagh ZK, Sayadi MH (2015) Siting MSW landfills using MCE methodology in GIS environment (case study: Birjand plain, Iran). Waste Manag 46:322-337. https://doi.org/10.1016/j.wasma n.2015.08.013

Nas B, Cay T, Iscan F, Berktay A (2010) Selection of MSW landfill site for Konya, Turkey using GIS and multi-criteria evaluation. Environ Monit Assess 160:491-500

Natesan U, Suresh ESM (2002) Site suitability evaluation for locating sanitary landfills using GIS. J Indian Soc Remote Sens 30:261264. https://doi.org/10.1007/BF03000369

Nishanth T, Prakash MN, Vijith H (2010) Suitable site determination for urban solid waste disposal using GIS and remote sensing techniques in Kottayam Municipality, India. Int J Geomat Geosci $1: 197-210$

Pal S (2015) Identification of soil erosion vulnerable areas in Chandrabhaga river basin: a multi-criteria decision approach. Model Earth Syst Environ. https://doi.org/10.1007/s40808-015-0052-z

Pasalari H, Farzadkia M, Gholami M, Emamjomeh MM (2019) Management of landfill leachate in Iran: valorization, characteristics, and environmental approaches. Environ Chem Lett 17:335-348. https://doi.org/10.1007/s10311-018-0804-x

Patil MP, Subramani T, Patil SA, Chakrabarti T (2002) Multi-level screening of a proposed hazardous waste treatment and disposal facility—a case study. Environ Monit Assess 76:299-309

Peuquet DJ, Marble DF (1990) Introductory readings in geographic information systems. Taylor \& Francis, London

Rafiee R (2011) Site selection for waste transfer station with regard to urban growth trend-Mashhad case study. (University of Tehran), p 105

Raghupati L (1999) Remote sensing applications in siting of waste disposal facilities with special reference to hazardous wastes. In: Mukherjee S (ed) Remote sensing application in applied sciences. Manak Publications, New Delhi, pp 141-179

Rezaei-Moghaddam K, Karami E (2007) A multiple criteria evaluation of sustainable agricultural development models using AHP. Environ Dev Sustain 10:407-426

Saaty TL (1980) The analytic hierarchy process. McGraw-Hill, New York
Saaty TL (1990) How to make a decision: the analytic hierarchy process. Eur J Oper Res 48:9-26

Saaty TL (2012) Decision making for leaders: the analytic hierarchy process for decisions in a complex world, 3rd edn. RWS Publication, Pittsburg

Savage GM, Diaz LF, Golueke GC (1998) Guidance for land filling waste in economically developing countries. US Environmental Protection Agency. National Risk Management Research Laboratory, Cincinnati, OH, USA. EPA 600/R-98-040

Sener B, Suzen ML, Doyuran V (2006) Landfill site selection by using geographic information systems. Environ Geol 49(3):376-388. https://doi.org/10.1007/s00254-005-0075-2

Şener S, Sener E, Nas B, Karagüzel R (2010) Combining AHP with GIS for landfill site selection: a case study in the Lake Beysehir catchment area (Konya, Turkey). Waste Manag 30(11):20372046. https://doi.org/10.1016/j.wasman.2010.05.024

Şener S, Sener E, Karaguzel R (2011) Solid waste disposal site selection with GIS and AHP methodology: a case study in SenirkentUluborlu (Isparta) Basin, Turkey. Environ Monit Assess 173:533554. https://doi.org/10.1007/s10661-010-1403-x

Serwan MJB, Flannagan J (1998) Developing and implementing GISassisted constraints criteria for planning landfill sites in the UK. Plan Pract Res 13:139-151

Shah NS (2007) Burning quest: should public health be sacrificed to waste? Down To Earth, pp 25-26

Shrivastava R (2019) India's trash bomb: $80 \%$ of 1.5 lakh metric tonne daily garbage remains exposed, untreated, India Today. https:// www.indiatoday.in/india/story/india-s-trash-bomb-80-of-1-5lakh-metric-tonne-daily-garbage-remains-exposed-untreated1571769-2019-07-21. Accessed 17 Dec 2019

Suchitra M (2007) Outside: burnt or buried, garbage needs land. Down To Earth 15:22-24

Sumathi VR, Natesan U, Sarkar C (2008) GIS-based approach for optimized siting of municipal solid waste landfill. Waste Manag 28:2146-2160

Tavares G, Zsigraiová Z, Semiao V (2011) Multi-criteria GIS-based siting of an incineration plan for municipal solid waste. Waste Manag 31:1960-1972

Taylan V, Dahiya RP, Anand S, Sreekrishnan (2007) Quantification of methane emission from solid waste disposal in Delhi. J Resour Conserv Recycl 3:240-259

Tripathi RD, Rai UN, Baghel VS (2006) The challenges of solid waste. Sci Rep 5(1):39-42

Uyan M (2013) MSW landfill site selection by combining AHP with GIS for Konya, Turkey. Environ Earth Sci 71:1629-1639

Yaakup A, Zalina S, Sulaiman S (2004) Integrated land use assessment (ILA) for planning and monitoring urban development. Universiti Teknologi Malaysia.

Yadav KPS (2007) Pandora's garbage can. Down To Earth, pp 20-21

Yagoub MM, Buyong T (1998) GIS applications for dumping site selection. In: Proceedings of the ESRI international user conference 107

Yal GP, Akgün H (2013) Landfill site selection and landfill liner design for Ankara, Turkey. Environ Earth Sci 70:2729-2752. https://doi. org/10.1007/s12665-013-2334-y 